\title{
Reproductive strategies of benthic invertebrates in the Kara Sea (Russian Arctic): adaptation of reproduction modes to cold water
}

\author{
Ingo Fetzer ${ }^{1, *}$, Wolf E. Arntz ${ }^{2}$ \\ ${ }^{1}$ Helmholtz Center for Environmental Research (UFZ), Dept. Environmental Microbiology, Permoserstr. 15, 04318 Leipzig, \\ Germany \\ ${ }^{2}$ Alfred-Wegener-Institute for Polar and Marine Research, Columbusstrasse, 27568 Bremerhaven, Germany
}

\begin{abstract}
Many benthic invertebrates in the boreo-Atlantic region reproduce via pelagic larvae. Past investigations in polar areas suggested a greater predominance of species lacking a pelagic phase. In this study, the reproduction strategies of the main 88 species of the Kara Sea were investigated. Field observations were supplemented by literature studies (reproduction period and strategy, biogeographical affiliation). Larvae of 44 meroplanktonic species were identified, but adult forms of only 23 of these species are known from the region. For the other 21 larval types, adults were not present in the Kara Sea but have previously been recorded in the adjacent Barents Sea. Larval transport processes are thus potentially important for the import of species into the region. High numbers of species of temperate origin were common, and had a strong influence on the overall reproduction patterns of the region. The southern Kara Sea was mainly dominated by 2 groups: highly mobile crustaceans, which are obligate non-pelagic developers, and non-motile organisms with primarily pelagic reproduction modes. We propose that reproduction patterns are strongly influenced by the highly variable environmental conditions of the Kara Sea which, via ice-scouring and the high input of freshwater from the 2 adjacent rivers, regularly lead to a local depletion of the benthic species. The input of warm freshwater from the rivers enhances the survival of species with a boreal biogeographical distribution, which additionally contributes to the high number of species with pelagic development that were found. Overall, the reproduction modes of benthic invertebrates in the Kara Sea are thus strongly governed by the local environmental conditions characteristic of the region.
\end{abstract}

KEY WORDS: Arctic $\cdot$ Kara Sea $\cdot$ Benthos $\cdot$ Biogeography $\cdot$ Reproduction types $\cdot$ Reproduction period

\section{INTRODUCTION}

Marine invertebrates display a great variety of development modes. These modes may differ according to the ecological niche they occupy during development e.g. the spatial location of larvae (benthic vs. pelagic), trophic types (feeding vs. non-feeding), as well as the degree of parental care (free vs. protected) (Poulin et al. 2001). Each type is found in all marine realms but comparisons of the principal reproduction modes have shown that they are not equally distributed among geographic regions (Thorson 1936, Mileikovsky 1971, 1974, Poulin \& Féral 1998).

Thorson (1950) stated that more than $70 \%$ of the benthic invertebrates in the boreo-Atlantic regions repro- duce via pelagic larvae, which potentially enables dispersal over large distances. This is obviously advantageous, especially in the case of sessile and less mobile species (Scheltema 1989). It allows for the fast colonization of new territories (Thorson 1950), and avoids persistent inbreeding and intra-specific food competition between new recruits and adults (Grosberg \& Quinn 1986, Grosberg 1987). On the other hand, benthic development without a pelagic stage guarantees higher offspring survival rates since they are not endangered by drifting into unfavorable regions but rather remain at sites where the adults have survived.

In the first meroplanktonic surveys in polar waters conducted by Thomson (1878) the small number of 
pelagic larvae at high latitudes led to the assumption that in polar species the relative importance is shifted towards benthic development. The investigations of Thorson $(1936,1946,1950)$ supported this hypothesis, which later became known as 'Thorson's rule' (see Mileikovsky 1971). Thorson (1936) explained the predominance of benthic development in polar seas by the mismatch between the prolonged development times of pelagic developers due to metamorphosis and the shortage in food availability of plankton at high latitudes, apparently selecting against species with a pelagic life history (Pearse \& Lockhart 2004). His concept was supported by observations that many species at higher latitudes tend to produce larger but fewer yolk-rich eggs than their counterparts at lower latitudes, pointing to a non-pelagic, abbreviated developmental mode (Pearse 1994, Thatje \& Fuentes 2003). Additionally, in the southern polar hemisphere higher proportions of species with parental care and nonfeeding larvae were found (Pearse 1994).

Recently, larger numbers of pelagic larval types have been detected primarily in the shallow Antarctic waters, with a number of planktotrophs found even among the dominant species (Stanwell-Smith et al. 1999, Poulin et al. 2002). Pelagic development also seems to be more common than previously thought among Arctic benthic animals (Dayton 1990). Nonetheless, the percentage of species with pelagic development in Antarctic waters appears small when compared with the large number of benthic species in these waters. Moreover, larval peak abundances are estimated to be 2 to 6 orders of magnitude lower than in comparable data from temperate zones (StanwellSmith et al. 1999, Arntz \& Gili 2001). Stanwell-Smith et al. (1999) hypothesized that the low abundances found can be explained by dilution of the larvae over larger regional and temporal scales due to a reduced spawning synchrony of the adults and the long duration of the larvae in the water column. Today Thorson's concept, which has been partly replaced by one in which latitudinal shifts are observed in the proportions of planktotrophy and lecithotrophy among planktonic larvae (Clarke 1992, Pearse 1994, Poulin \& Féral 1998), is still one of the most debated topics in meroplankton research (e.g. Clarke 1992, Pearse 1994, Arntz \& Gili 2001, Gallardo \& Penchaszadeh 2001).

Most of the recent research on this topic has been done almost exclusively in Antarctic regions (Pearse \& Lockhart 2004). Due to the isolated status of this region, the development patterns of benthic invertebrates are more conspicuous. Among the benthic animals, exceptionally high proportions are pelagic-lecithotroph or show parental care. Poulin et al. (2002) explained this by selective extinctions of mainly planktotroph species during the last glacial period and the current ecological success of the pelagic planktotrophs. Alternatively, Thatje et al. (2005) hypothesize that the current rarity of broadcasters among Antarctic marine benthic invertebrates is a consequence of the total extinction of all species from the shelves. Antarctic species survival was only possible in the deep sea (promoting sheltered lecithotroph development modes) and for planktotrophs in discrete shelters on the continental shelf. Pearse \& Bosch (1994) suggested that the unique conditions of isolation resulting from the opening of the Drake Passage 30 million yr ago promoted new species formation of specious clades of brooders.

During the last glacial maximum in Arctic realms, however, extinction processes were similar to those in the Antarctic (Piepenburg 2005). But since the Arctic region never became isolated from the adjacent Pacific and Atlantic, a potential immigration of non-polar species of boreal regions tolerant to the polar conditions was still possible (Zenkevitch 1963, Dayton et al. 1994). As a consequence, regions with favorable environmental conditions can be preferably populated by species other than those with an Arctic biogeographical distribution, thus altering the overall ratio of development modes towards those more characteristic of boreal regions. Moreover, in regions with unstable environments where the immobile adult benthic organisms are periodically erased (e.g. due to ice-scouring) reoccupation by species with pelagic development should be favored (Palma et al. 2007). It is still unknown how far the interrelationship between local environmental characteristics and species composition affects the presence of certain reproductive traits in order to ensure the survival of species within a region. Therefore, we investigated development modes of benthic invertebrates of the Arctic Kara Sea. Generally, the waters of this polar region are characterized by low water temperatures, high salinity and oligotroph conditions (Volkov 2002). The Kara Sea is an 'intermediate' sea, the western part being influenced by the boreal Barents Sea while the eastern region borders on the high Arctic Laptev Sea. The Ob and Yenisei Rivers discharge large amounts of freshwater into the adjacent shallow marine realm, significantly altering the thermal, saline and nutrition regime of the Kara Sea on a regional scale through the constant input of warm, low salinity and highly nutrient-loaded waters (Pavlov \& Pfirman 1995, Volkov 2002).

The aims of this study are (1) to give a first indication of the main development modes prevailing for the benthic invertebrates of the Kara Sea, (2) to investigate the adaptation in life history traits of the benthic species and (3) to investigate how far local environmental characteristics have an influence on the prevailing species and thus also on the overall reproductive traits of the Kara Sea species. In addition to field data 
on adults, juveniles and planktonic larvae gathered during several expeditions, a general overview of the development modes of the main benthic invertebrates is compared with findings from the literature together with the biogeographical affiliations of the adult species occurring.

\section{MATERIALS AND METHODS}

Study area. The Kara Sea is located on the shallow Siberian shelf, which in its central part hardly exceeds a depth of 40 to $50 \mathrm{~m}$ (Fig. 1). The area has an open boundary with the Arctic Basin to the north while it is framed in the west by the St. Anna trough (maximum depth $600 \mathrm{~m}$ ), which stretches along the east coast of Novaya Zemlya. To the east, Severnaya Zemlya and the Taymyr peninsula separate the Kara Sea plateau from the Laptev Sea (Cherkis et al. 1991). Seasonal water exchange with the Barents Sea proceeds through the Kara Strait between the Siberian mainland and Novaya Zemlya as well as around the northern tip of the island. Waters from the Arctic Ocean and the Laptev Sea periodically wash into the area from the north and along Severnaya Zemlya through the Vilkitski Strait.

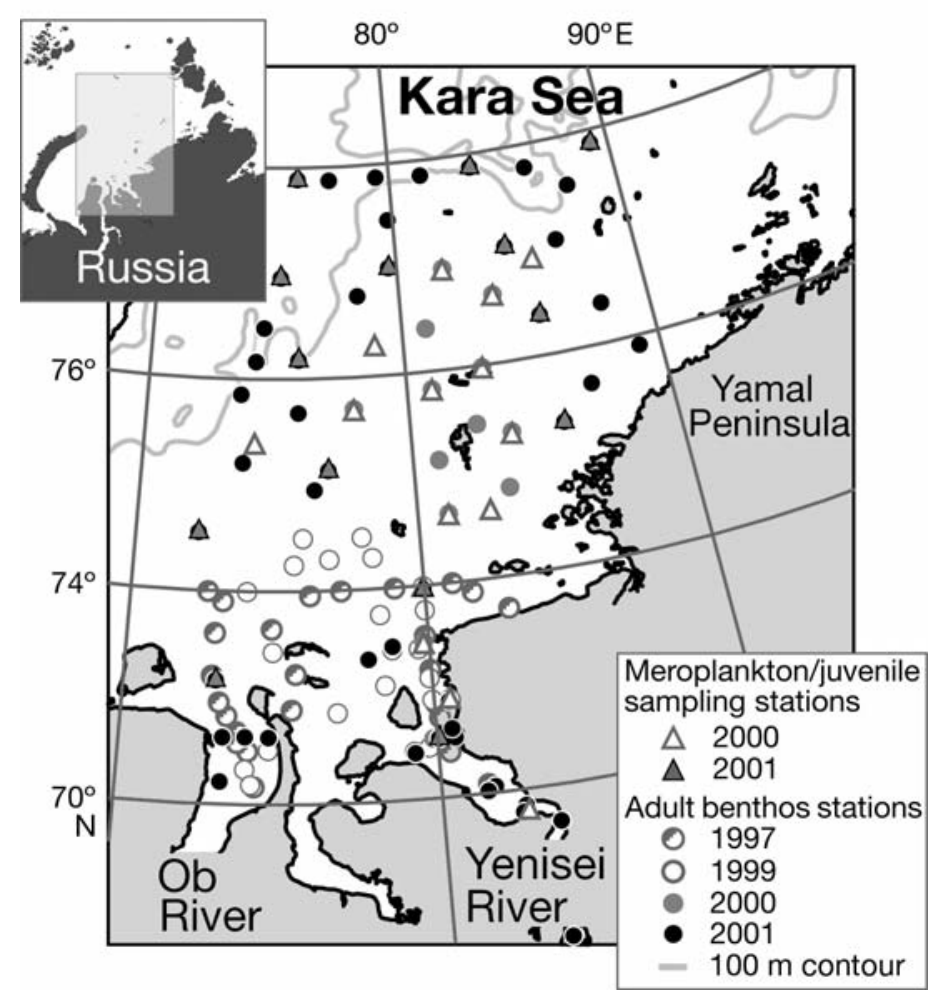

Fig. 1. Sampling area in the Kara Sea, with location of adult benthos stations in 1997, 1999, 2000 and 2001, and meroplankton/juvenile sampling stations in 2000 and 2001
The Kara Sea is covered by ice for about 9 mo of the year (Blanchet et al. 1995). Ice formation usually starts at the end of October and break-up coincides with the main river discharge of the 2 largest rivers $\mathrm{Ob}$ and Yenisei in early to late June (Mironov et al. 1994).

Sampling. Adult fauna were analyzed during 4 expeditions to the Kara Sea on board RV 'Akademic Boris Petrov' in 1997, 1999, 2000 and 2001 (Fig. 1). All expeditions took place in the period August-September of each year. Samples were collected at 26 stations in 1997, 24 stations in 1999 and 16 stations in 2000. Since the bottom in the study area consists mainly of medium to very soft sediments with occasional pebbles and shells, benthos samples were taken with a large box corer $\left(0.25 \mathrm{~m}^{2}\right.$ coverage area) and a dredge ('Kieler Kinderwagen', frame size $150 \times 50 \mathrm{~cm}$ ). Animals were extracted by rinsing sediments on $500 \mu \mathrm{m}$ screens, and preserved in $6 \%$ borax-buffered formalin.

For meroplankton and juvenile investigations, specimens were sampled at 30 stations during each expedition in 2000 and 2001 (Fig. 1). Meroplanktonic larvae were caught with a vertically hauled Nansen net (0.442 $\mathrm{m}^{2}$ catching area, $55 \mu \mathrm{m}$ mesh size, $0.5 \mathrm{~m} \mathrm{~s}^{-1}$ hauling speed). The sampling depths varied between $6 \mathrm{~m}$ in the southeastern part of the sampling area to about $200 \mathrm{~m}$ in the northwest (for details see Deubel et al. 2003). Samples were then directly sorted for meroplankton under a stereo-microscope and the specimens preserved in Carriker solution (a $\mathrm{Na}_{2} \mathrm{CO}_{3}$-buffered sugar-formalin solution).

To study the distribution of already settled juveniles or released offspring of species with benthic development modes, multicorer samples $\left(280 \mathrm{~cm}^{2}\right.$ coverage area per tube) were taken (Fig. 1). At each station, 6 tubes were deployed. The upper 10 to $15 \mathrm{~cm}$ of each core was taken and screened over a sieve column into fractions of 500, 250, and $125 \mu \mathrm{m}$. All animals found in each fraction were extracted and preserved in $70 \%$ ethanol. Additionally, adult animals possessing brood pouches (e.g. amphipods or bivalves) were carefully inspected in the laboratory for juveniles or eggs.

Taxonomic identification. All animals were identified to the lowest possible taxon. For juveniles the body length of each specimen was measured with a microscale to $\pm 10 \mu \mathrm{m}$. Measurements were only conducted on complete animals. Juveniles were defined as immature specimens less than $1 / 3$ of mean adult size according to the literature (e.g. Hartmann-Schröder 1996 for polychaetes). Many larvae and juveniles could not be directly determined to the species level. Therefore, the comparison of larvae, juveniles and the local adult fauna was often necessary to match larvae and juveniles to adult species. 
Reproduction types. For the classification of development patterns in benthic marine invertebrates Poulin et al. (2001) propose a comprehensive scheme of different niche occupation by the offspring during their development. They distinguish development patterns by habitat (pelagic vs. benthic development), physically free vs. protected (brooded) development of the larvae and by the mode of nutrition uptake (feeding vs. non-feeding). Since reproduction strategies often cannot be confined exclusively to one of these groupings, and larval types thus often possess transitive characteristics between the extremes, they proposed a multispaced model to place all larval types.

However, in contrast to the more comprehensively investigated Antarctic regions (e.g. Bosch \& Pearse 1990, Clarke 1992, Hain \& Arnaud 1992, Chiantore et al. 2002) little information exists on the development modes of Arctic animals. Due to the limited knowledge of Arctic meroplankton ecology of species present in the Kara Sea, the development types were classified by the habitat occurrence of the larvae (i.e. the most apparent characteristic), with reference to existing literature. This approach represents only one aspect of the multidimensional approach given by Poulin et al. (2001) and should be seen as a first approximation for investigating planktonic development modes in the Kara Sea. However, this approach allows one to make predictions on the relationship between pelagic and benthic development traits of benthic animals as an adaptation to the environment in the investigated area and the adjacent Arctic seas. It also helps to estimate the species' potential ability to disperse (see also Tables 1 \& 2). All species have therefore been placed in one of the following categories:

- Pelagic: species with a defined pelagic larval stage

- Pelagic?: species with a presumed pelagic larval stage

- Short pelagic or demersal: species with a short pelagic phase or demersal larvae

- Benthic: species lacking a pelagic phase

- Benthic?: species with presumed non-pelagic development

- Unknown: species with undetermined development mode

For the classes 'pelagic?' and 'benthic?' the reproduction mode was assumed to be pelagic or benthic but either the literature was inconclusive on this point or it was not confirmed by our own observations.

Life history and biogeographical distribution of species. Life-history traits and the biogeographical distribution of the adult benthic species were determined from the literature (see 'Comments' in Tables 1 \& 2). Known reproduction types, time of spawning, reported presence of eggs and/or ripe females, and duration of the pelagic stage in the water column of each species were summarized and compared with field data. Since for many species the real duration of the larval time is uncertain, question marks have been used in the tables to indicate the proposed presence for the species.

\section{RESULTS}

\section{Biogeographical distribution of benthos}

For the benthic species, the adults of 88 species were found during the expeditions in the Kara Sea (Table 1). Most of these belonged to the Polychaeta (45 species; $51 \%)$. The next largest group was the Crustacea containing 25 species (28\%). Crustacea were exclusively composed of the groups Cumacea ([Brachy-]Diastylis spp. and Leucon spp.), Isopoda (Saduria sibirica) and Amphipoda. Mollusca contributed 13 species (15\%) to the total. Except for Cylichna cf. occulta (Gastropoda) all species within this group were Bivalvia. Only 5 species $(6 \%)$ belonged to the echinoderms, which were composed of the 3 groups Asteroidea (Ctenodiscus crispatus), Holothuroidea (Eupurgus scaber, Myriotrochus eurycyclus, Myriotrochus rinki), and Ophiuroidea (Ophiocten sericeum).

With regards to the biogeographical distribution, 41 species $(47 \%)$ were of Arctic origin, while 32 species (36\%) had an Arctic-boreal distribution. Another 4 species $(4.5 \%)$ were assigned to boreal regions, while 11 species $(12.5 \%)$ were cosmopolitans. Cosmopolitans were exclusively polychaetes, whereas no taxon dominated among the Arctic-boreal and Arctic species. Larvae of $26 \%$ of the benthic species were found in plankton samples, accounting for 23 different larval types (Table 1). Most (19 larval species) belonged to the polychaetes, and 4 species to the echinoderms, whereas no larvae of the adult crustacean and mollusc species were detected. Of the larvae found, 16 types could be definitely identified at the species level.

Juveniles of 52 benthic species (59\% of adult species) were found. Of these, 39 juvenile types could be determined at the species level. The biggest share of juveniles found belonged to the Polychaeta (30 species), with 9 species belonging to the Mollusca, 8 species to the Crustacea and 5 species to the Echinodermata. No ripe female crustaceans were detected during the study period. Additionally, 21 larval types were identified belonging to species whose adults were not found in the Kara Sea (Table 2). According to the literature, 8 of these are of Arctic-boreal origin. Another 4 species were cosmopolitans. Mollusc larvae found were exclusively of an Arctic biogeographical distribution. 


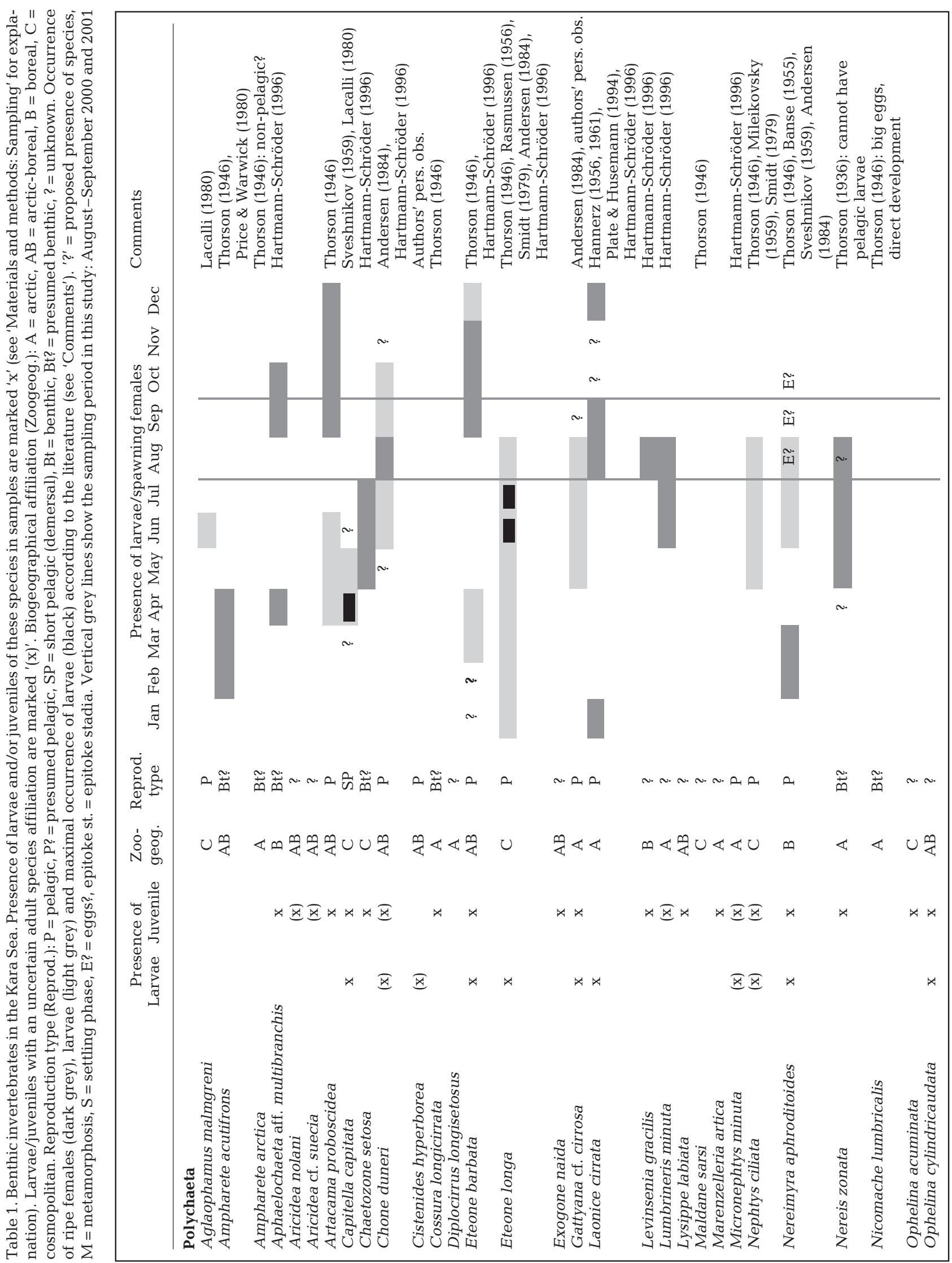




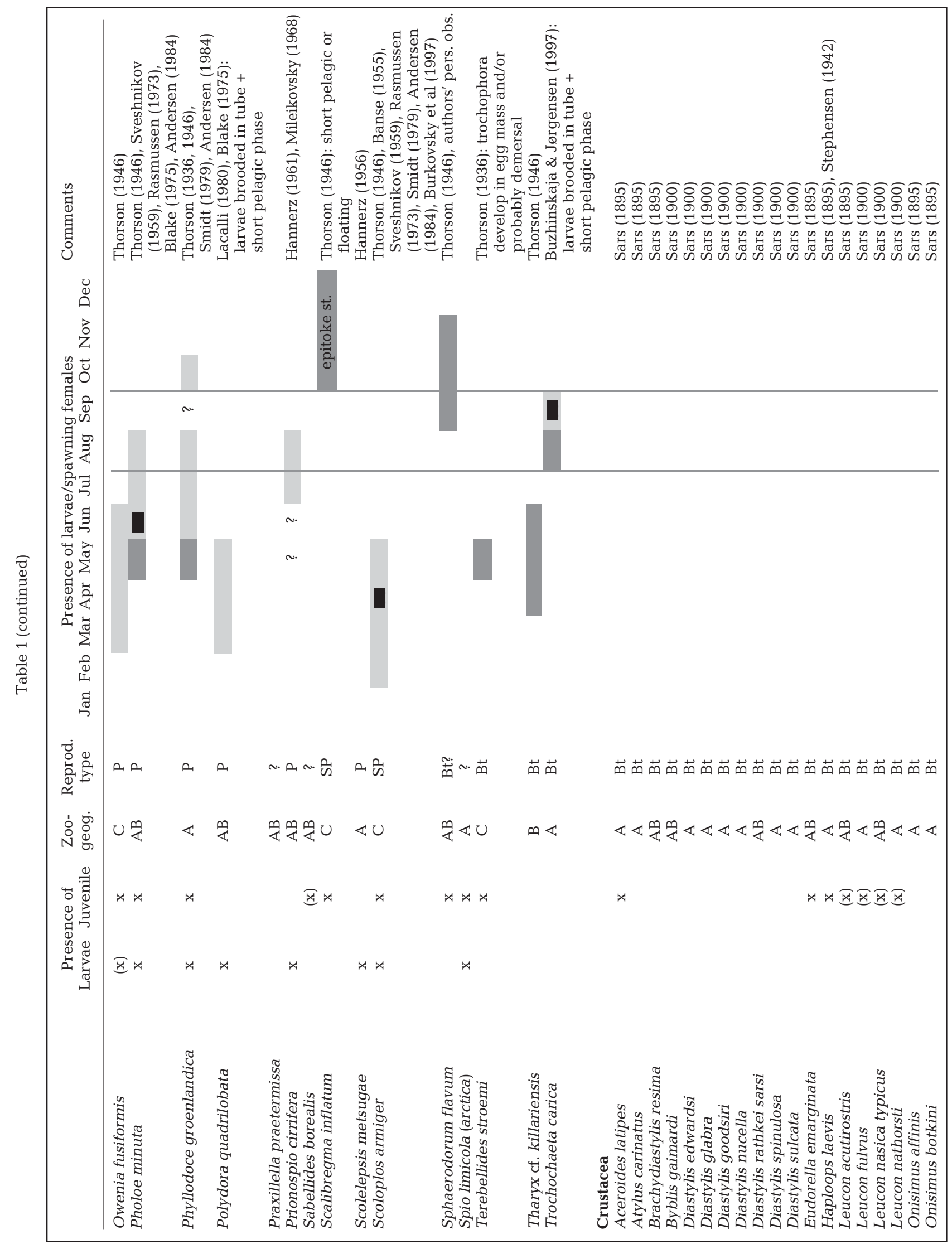




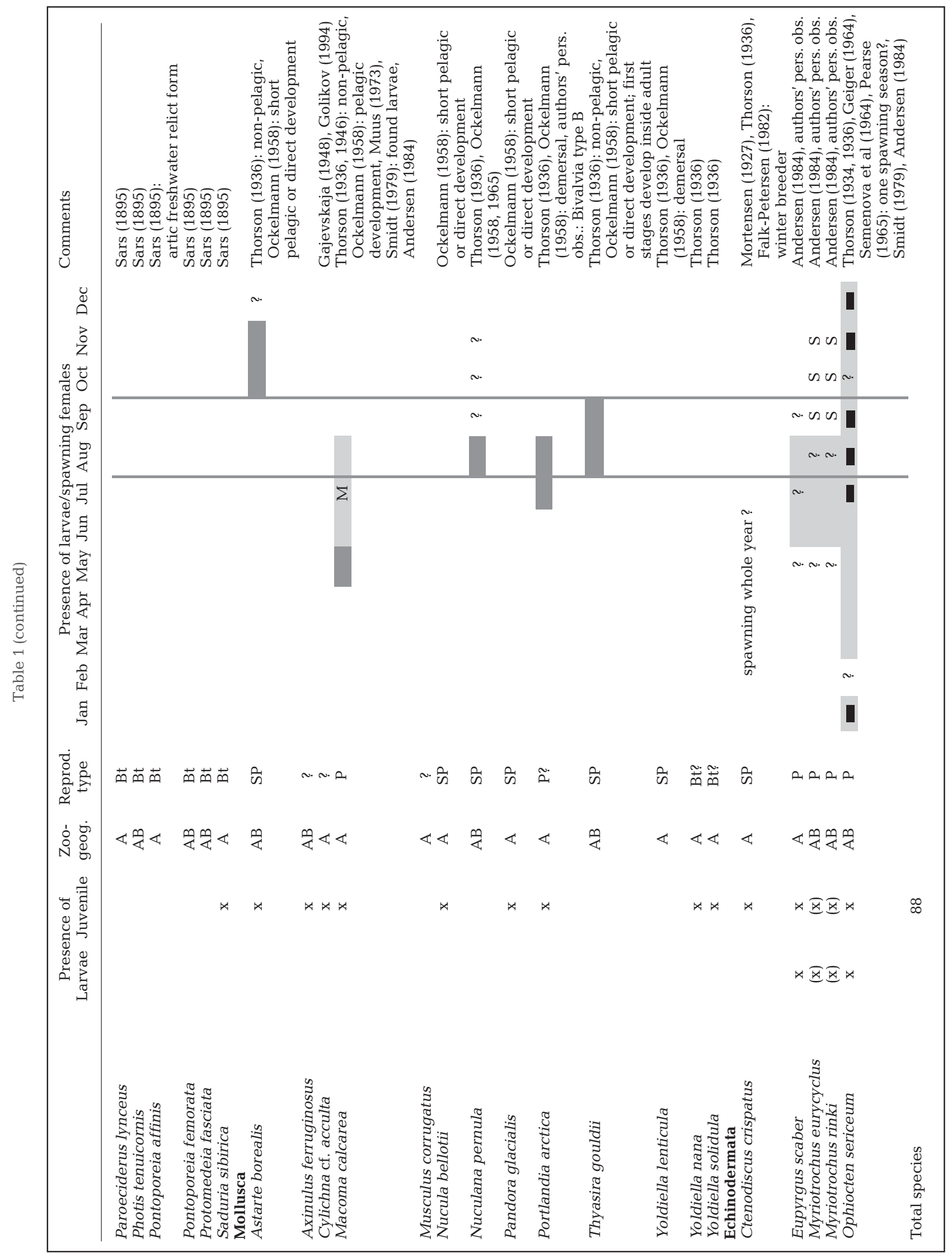

(Table continued on next page) 


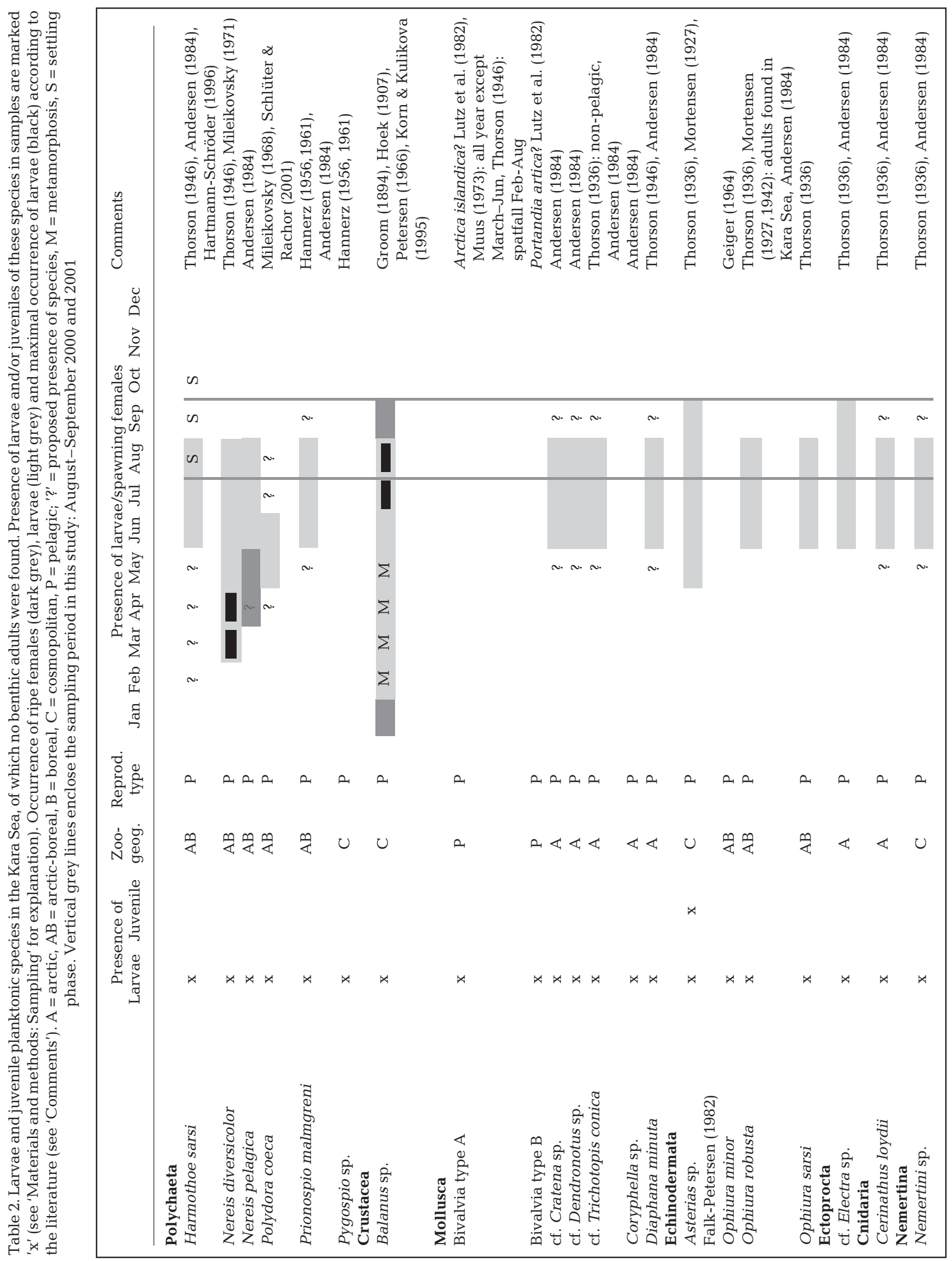




\section{Presence of larvae and juveniles: field data vs. literature}

Comparing the time of occurrence of meroplanktonic larvae in the water column of sampled data with data of earlier investigations from the literature (e.g. Thorson 1936, Gajevskaja 1948, Ockelmann 1958, Hannerz 1961, Andersen 1984; see 'Comments' in Table 1), reveals that for the period August/September (time of expeditions) the occurrence of 12 of the 23 larval types found corresponds to the spawning period estimated in earlier studies (Table 1). In addition, 6 polychaete species (Cistenides hyperborea, Laonice cirrata, Micronephtys minuta, Ophelina cylindricaudata, Scolelepis metsugae, Spio limicola [arctica]) were present in August/September. For the polychaete larvae (Capitella capitata, Eteone barbata, Owenia fusiformis, Polydora quadrilobata and Scoloplos armiger) the field findings do not correspond with the occurrence times given in the literature. For these species the reproduction period is reported to be earlier in the year (e.g. Thorson 1946, Sveshnikov 1959, Lacalli 1980, Hartmann-Schröder 1996; see Table 1). Polychaeta and Echinodermata are the best investigated groups. Nothing is reported on the larval period of most Mollusca. None of the crustaceans found have pelagic larvae; this group consisted only of peracarid taxa (Amphipoda, Isopoda, Cumacea), in which a pelagic reproduction trait is completely absent.

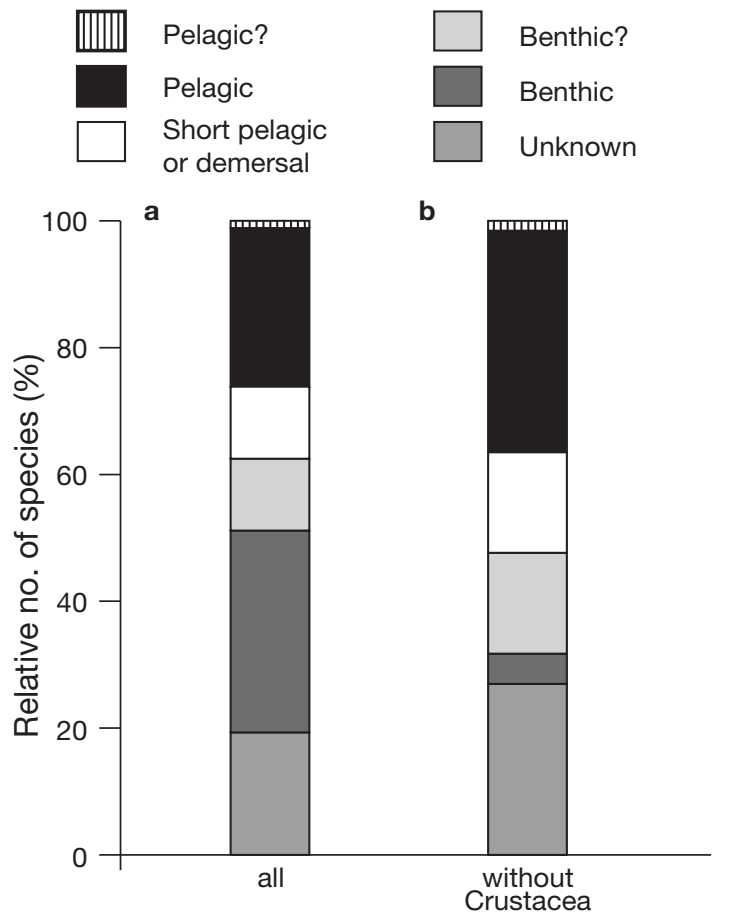

Fig. 2. Reproduction modes of the adult benthos either for all species, or all excluding Crustacea (for explanation see 'Results: Reproduction strategies')
Checking the coincidence of juveniles with the respective larvae is more difficult because it is unknown when they have settled (for species with pelagic development) or hatched from their eggs (benthic developing species). However, assuming an age of no more than 3 mo after settlement or release from their parents, the presence of 24 of the 32 juvenile species fitted with occurrence times given in the literature (Table 1). Nothing is known about the occurrence of the juveniles of 25 species found in the benthos. There were only 3 species (Scalibregma inflatum, Sphaerodorum flavum, Astarte borealis) for which the theoretical settlement times did not correspond to our observations.

Literature data (Table 1) reveal that apparently most species show benthic development ( $33 \%=28$ species) without a pelagic phase. Only $25 \%$ (22 species) have planktonic larvae (Fig. 2). In 11\% (9 species) benthic development is presumed, but has not as yet been proven. Another $11 \%$ (9 species) seem to have a short pelagic stage. In $1 \%$ (1 species = Portlandia arctica) pelagic larvae are assumed.

\section{Reproduction strategies}

Both Arctic Mollusca and Polychaeta show a broad spectrum of reproduction strategies (Fig. 3). Most Polychaeta species reproduce via pelagic larvae. However, in $>30 \%$ of polychaete species reproduction modes are still unknown. Benthic development plays only a subordinate role within this group. Short pelagic develop-

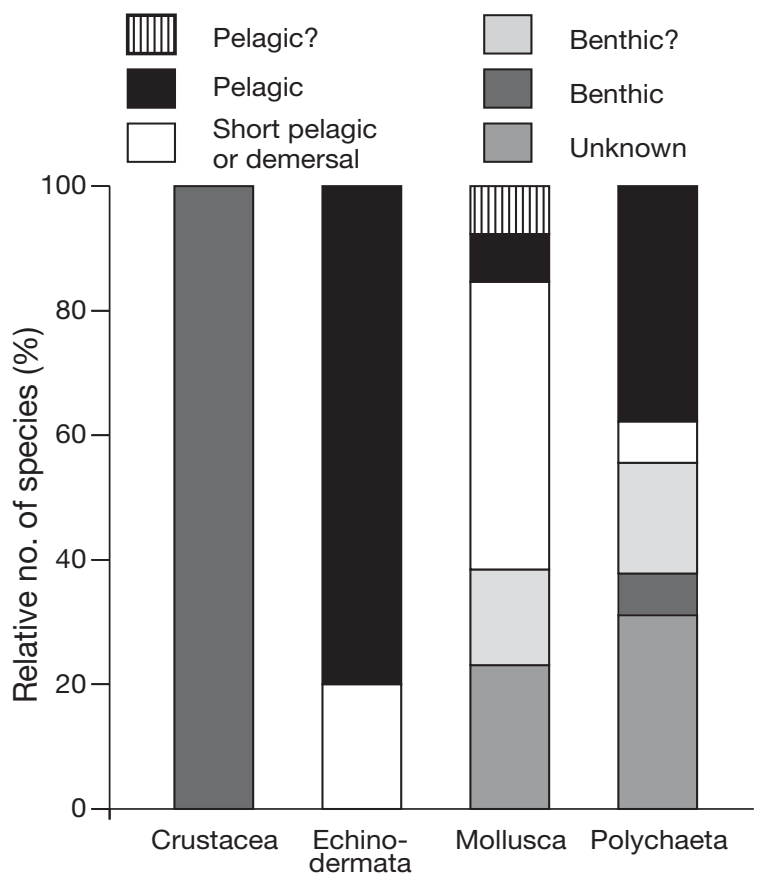

Fig. 3. Reproduction modes of benthic species found in the Kara Sea 
ment dominates the life cycle strategy of Mollusca. Here again, the development mode is unknown in about $20 \%$ of the species. With echinoderms, on the other hand, pelagic development strategies clearly dominate. In all crustaceans found during the expeditions in the Kara Sea benthic development occurs.

A comparison of known reproduction types for all adult species found with their biogeographical distribution reveals that the proportion of benthic development is obviously greatest in animals of Arctic distribution $(49 \%)$ and decreases continuously from Arctic-boreal (38\%) and boreal (33\%) species to only $11 \%$ in cosmopolitans (Fig. 4a). Pelagic development

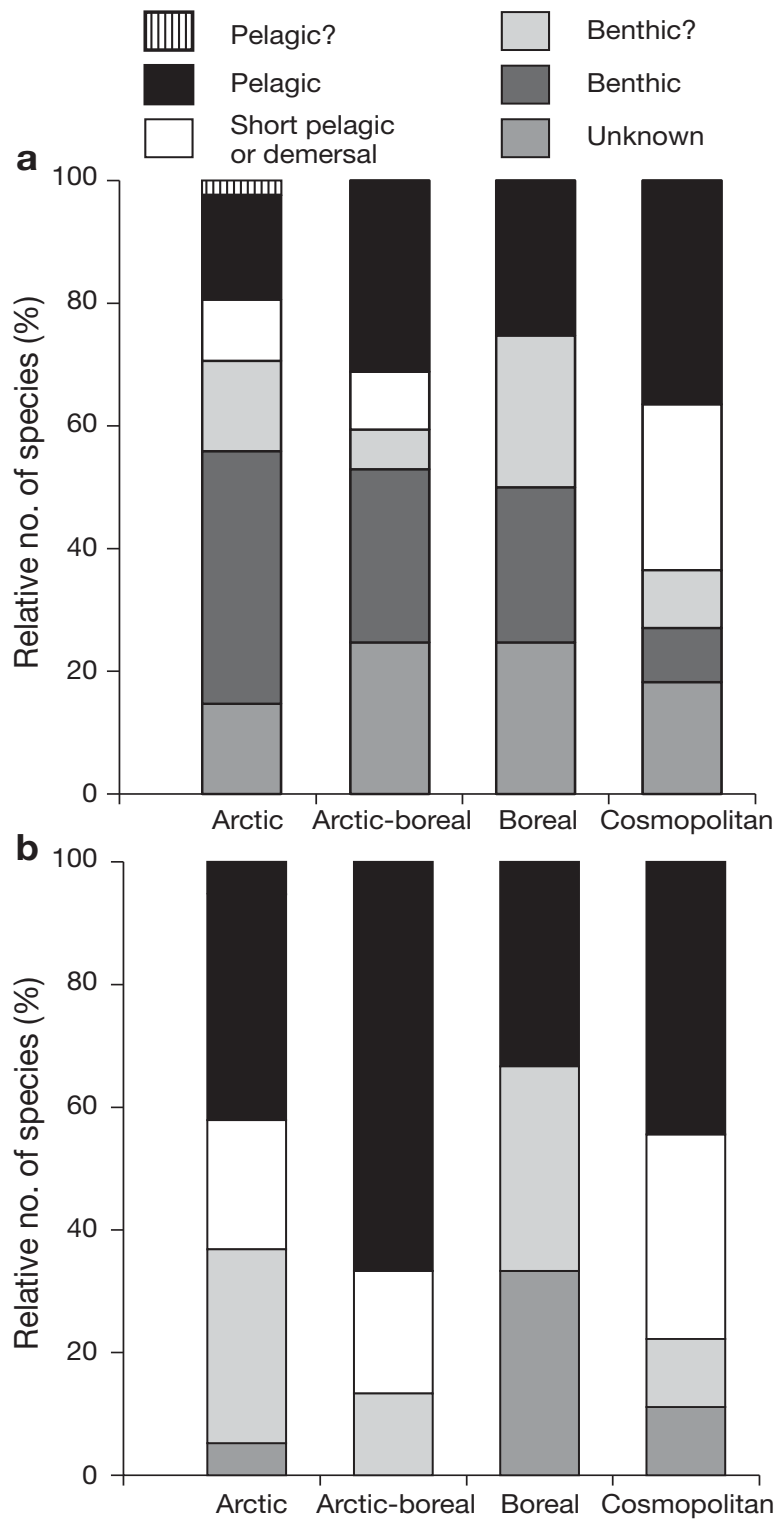

Fig. 4. Reproduction modes and biogeographical affiliation of the adult benthos for (a) all species, and (b) all species excluding Crustacea (for explanation see 'Results: Reproduction strategies') dominates among Arctic-boreal (42\%), boreal (33\%) and cosmopolitan (44\%) species. Short pelagic larval life is of importance in Arctic (11\%), Arctic-boreal $(13 \%)$ and in cosmopolitan (33\%) species, but seemingly absent in species with a boreal affiliation. Here benthic development is attributed in $33 \%$ of all adult species.

The highest numbers of species found in the Kara Sea are crustaceans that exclusively have a benthic development mode, irrespective of their biogeographical status (Table 1, Fig. 3). To remove this bias, the relationships were re-examined for all species excluding crustaceans. The results reveal a different picture concerning the importance of benthic development among Arctic species.

When excluding crustaceans, pelagic development is the prevailing life strategy in $37 \%$ of all species as opposed to $5 \%$ displaying benthic development (Fig. 2). Benthic development is assumed in $32 \%$ of the Arctic species (Fig. 4b). In $21 \%$ of the species a short pelagic pattern dominates. In Arctic-boreal species pelagic development is the main reproduction type $(67 \%)$. About $20 \%$ of the species have short-pelagic or demersal larvae. Species with a known benthic development are virtually absent in this biogeographical unit. Benthic development is assumed in $13 \%$ of the species. Since the Cumacea, Amphipoda and Isopoda found consisted only of Arctic and Arctic-boreal species, the reproduction types in boreal and cosmopolitan species remain unchanged.

\section{DISCUSSION}

\section{Species biogeography}

Most of the adult species found in the Kara Sea have an Arctic biogeographical distribution. Arctic-boreal and boreal species continuously decrease in numbers with increasing distance from their biogeographical origin. Curtis (1975) noted that, when no distribution barriers exist, faunistic differences in Arctic and subArctic regions are generally not extreme, since many warm- and cold-water species are found in more than one biogeographical zone. Ekman (1953) found that $75 \%$ of the fish genera observed in the Arctic are also present in temperate waters, and $8 \%$ are common in temperate and subtropical regions.

The faunal composition of the Kara Sea is generally strongly influenced by Arctic waters. However, water exchange with the Barents Sea also supports immigration of Arctic-boreal and boreal species. Moreover, the import of relatively warm river water from the $\mathrm{Ob}$ and Yenisei Rivers into the area may facilitate the survival of boreal, eurytherm species. 


\section{Meroplankton composition}

Comparison of larval composition with other studies is often difficult, since meroplankton assemblages undergo considerable successional changes (Raymont 1983). The occurrence of larvae depends in principle on the composition of the benthic communities, but their distribution patterns are strongly shaped by the local hydrography, resulting in different compositions even if the benthic communities are identical (Mileikovsky 1968, Clough et al. 1997, Schlüter \& Rachor 2001).

However, the meroplankton species composition in the Kara Sea roughly resembles the assemblage found by Schlüter \& Rachor (2001) in the Barents Sea, although the latter survey was conducted some months earlier in the year (May/June). As with the Kara Sea, the Barents Sea meroplankton was dominated by polychaete species. By far the most comprehensive studies on meroplankters in polar waters have been made by Andersen (1984) and Smidt (1979). Although they investigated a fjord in north (Andersen 1984) and southwest Greenland (Smidt 1979), their inventory contained all larval species present in the Kara Sea. This provides evidence that the main pelagic reproducing species have a very broad distribution in the Arctic realm and/or indicates a high distribution potential of pelagic larvae.

Long-distance transport processes or a result of water exchange from the adjacent Barents Sea may be responsible for our finding larvae whose adult stages are lacking in the Kara Sea (Table 2). Periodical water exchange with the Barents Sea occurs through the Kara Strait or around the northern tip of Novaya Zemlya (Volkov 2002). These larvae most probably spawned in the Barents Sea and were transported into the Kara Sea. Planktotrophic larvae of boreal species typically require 2 to 6 wk before settling (Day \& McEdward 1984), during which time currents can transport larvae and juveniles over distances of 100 to 1000 km (Mileikovsky 1966, 1968).

Faunistic investigations by Zenkevitch (1963) and Sirenko (2001) revealed the presence of the missing adult species from the adjacent Barents, Petchora and White Seas. Therefore, these seas obviously can serve as an important source for the import of new species into the Kara Sea.

The gastropods (Cratena sp., Dendronotus sp., Trichotopis conica, Coryphella sp.), Ectoprocta (Electra sp.) and the cirripede Balanus sp. larvae present in the samples are typical of rocky bottoms, and untypical for the soft-bottomed Kara Sea. They most probably originate from the nearby Novaya Zemlya Islands or the shore of the mainland. The few larval and adult species indicate that species associated with rocky bottom only play a minor role in the Kara Sea.
The surprisingly high numbers of planktotrophic larvae found during the survey provide evidence that the environment does not select against planktonic larvae in the way Thorson $(1936,1946,1950)$ proposed. Thorson (1950) thought that the prolonged development of planktotrophic larvae, characteristic of polar species, would not permit them to get enough food during the short period of phytoplankton production. The present study provides strong argument against this notion. Indeed, the finding of so many larvae of species that are rare or absent in the Kara Sea suggests that there is no selection against the larvae preventing their establishment there. However, import of nutrients through the $\mathrm{Ob}$ and Yenisei Rivers may extend the feeding period for larvae and support their survival.

\section{Reproduction modes and biogeographical affiliation}

The onset of the last glacial and interglacial periods induced pronounced global sea-level variations over intervals of $100 \mathrm{~m}$, which have repeatedly drained the shelf regions of the Arctic ocean and/or (partly) covered them by huge glaciers. The last such glacial event occurred only 13000 yr ago (Zenkevitch 1963). Thus, the Arctic Shelf is not only inhabited-in evolutionary terms - by 'young' benthic assemblages, but also had to be repeatedly recolonized by marine fauna (Piepenburg 2005).

The biogeographical affiliation pattern of the benthic species in combination with their reproduction modes seems to reflect the colonization pattern of the shelf area, given that the Arctic species were the first colonizers on the Kara Sea shelf and it was only as the Kara Sea became gradually warmer that they were followed by species with Arctic-boreal and boreal affiliations (Fig. 4). Limited or no dispersal abilities are mainly found among species with an Arctic biogeographical status. On the other hand, species with larvae that can be transported over long distances are found mainly among taxa originating from boreal regions. This may reflect the young evolutionary status of the region as stated above, since no boreal species with limited or no dispersal abilities have as yet invaded the region. The strong correlation between biogeographical affiliation and dispersal abilities is also an indication that so far no evolutionary adaptation has occurred, i.e. a high dispersal and recolonization potential is most evident in species with a boreal affiliation, while Arctic species obviously lack these characteristics.

Interestingly, species with short pelagic or demersal development are most common among cosmopolitan species. However, this reproduction mode seems to also be important among the other biogeographical 
types. Distribution via short pelagic or demersal larvae is advantageous since it provides a good balance between the dispersal abilities of a species, thus maintaining the potential for the recolonization of new territories, but also avoids the drifting away from favorable parental settling grounds. Therefore, a short drifting period keeps the survival rate at a maximum and additionally allows the offspring to find new favorable sites close to the parental settling grounds. Retention of larvae, especially within the river-influenced southern parts of the Kara Sea has been found to be crucial for some species (Fetzer \& Deubel 2006).

\section{Pelagic vs. non-pelagic development}

At first sight, the reproductive development modes in the Kara Sea show an obviously higher proportion of benthic to pelagic developing species, which is in agreement with the concept proposed by Thorson (1936, 1950) and Mileikovsky (1960, 1971) (Fig. 2a). This tendency becomes even more distinct when displaying the reproduction types according to their biogeographical range. Here, the highest numbers of nonpelagic developing species are found among Arctic specimens, decreasing gradually when moving from Arctic species towards those with a boreal distribution (Fig. 4a).

However, careful analysis of the species composition (Fig. 3) reveals that the high share of benthic developing species can be attributed to the high numbers of peracarid species found in the study area. As mentioned earlier, within the taxonomic group Peracarida only one reproduction strategy (no larvae, juveniles kept in brood pouches) is predominant, irrespective of the geographical region they inhabit. In our study, a high proportion ( $64 \%=16$ species) of the peracarids are exclusively confined to Arctic regions (Table 1). On an evolutionary timescale species lacking a dispersal phase have been suggested to exhibit a much higher speciation rate than species distributing via larvae (Jablonski \& Lutz 1983, Duda \& Palumbi 1999, Jablonski \& Roy 2003). Species with a limited dispersal rate therefore evolve more readily into new species that are better adapted to the Arctic environment. This may explain a higher endemism in polar waters for many peracarid crustaceans with benthic development.

Omitting the peracarid species from the data set, pelagic development becomes the main reproductive strategy in the Kara Sea realm (Fig. 2). This, however, is somewhat contrary to the traditional view on reproduction modes in the Arctic. Thorson (1950) reported that only $5 \%$ of Arctic marine invertebrates reproduce by larvae in polar realms, a value that is clearly too low in the light of the studies cited above. However, in con- trast to many parts of the polar zone, the Kara Sea shelf is a comparatively unstable environment. The shallow parts of the Kara Sea in particular are characterized by a pronounced inter-annual seasonality in the icecoverage, river discharge, and sedimentation rates complemented by strong intra-annual fluctuations (e.g. Makkaveev \& Stunzhas 1994, Pavlov \& Pfirman 1995, Volkov 2002). Benthos communities are periodically reduced by freshwater discharge and ice scouring. Accumulations of large numbers of bivalve shells found in sediment cores of bottom surface layers indicate occasional mass mortality among benthic organisms (Stein 2001, Stein \& Levitan 2002). The instability of the regime obviously promotes fast recolonizing species with planktonic larvae and highly mobile species such as amphipods and isopods (Mileikovsky 1971, Santos \& Simon 1980, Burkovsky et al. 1997). Johst \& Brandl (1997) found that low dispersal (benthic development) is favored in spatially heterogeneous and temporally constant environments whereas high dispersal (pelagic development) is dominant in a spatially homogeneous or temporally varying environment. The fact that species with planktonic larvae have a much higher potential to occupy new territories may additionally explain the relatively high number of species with pelagic larvae (even among the Arctic species) in contrast to the findings of Thorson (1936).

Acknowledgements. We thank the officers and crew members of the RV 'Akademik Boris Petrov' as well as all the participants of the cruises in 2000 and 2001 for their support and help, especially M. Engel, I. Suck, V. Khorshev and A. Latko for their help during sampling. We also thank S. Gagaev and E. Barwich for their great help with identifying the polychaete larvae and $\mathrm{H}$. Deubel for giving us access to his adult benthos data. Moreover, we thank M. Schlüter, E. Poulin and J. Pearse and 2 anonymous referees for the very helpful comments on the MS. Many thanks to K. Smith for the English revision of the manuscript. This work was supported by BMBF 03G0539A1, Project Siberian River Run-Off (SIRRO).

\section{LITERATURE CITED}

Andersen OGN (1984) Meroplankton in Jørgen Brønlund Fjord, North Greenland. Medd Gronl 12:1-25

Arntz WE, Gili JM (2001) A case for tolerance in marine ecology: let us not put out the baby with the bathwater. Sci Mar 65:283-299

Banse K (1955) Über die Entwicklung von Castalia punctata (O.F.Müller), (Hesionidae, Polychaeta). Veroeff Inst Meeresforsch Bremerhaven 4:17-24

Blake JA (1975) The larval development of Polychaeta from the Northern Californian Coast. III. Eighteen species of Errantia. Ophelia 14:23-84

Blanchet D, Wilkman G, Golovin N, DeFranco S (1995) Ice expedition in the Kara Sea in 1993. Proc 2nd Int Conf Dev Russian Arctic Offshore (RAO-95). St. Petersburg State Technical University, St. Petersburg, p 9-15

Bosch I, Pearse JS (1990) Developmental types of shallow- 
water asteroids of McMurdo Sound, Antarctica. Mar Biol 104:41-46

Burkovsky IV, Udalov AA, Stoljarov AP (1997) The importance of juveniles structuring a littoral macrobenthic community. Hydrobiologia 355:1-9

Buzhinskaja G, Jørgensen L (1997) Redescription of Trochochaeta carica (Birula, 1897)(Polychaeta, Trochochaetidae) with notes on reproductive biology and larvae. Sarsia 82: 69-75

Cherkis NZ, Fleming HS, Max MD, Vogt PR and others (1991) Bathymetry of the Barents and Kara seas. Geological Society of America, Boulder, CO

Chiantore M, Cattaneo-Vienetti R, Elia L, Guidetti M, Antonini M (2002) Reproduction and condition of the scallop Admussium colbecki (Smith 1902), the sea-urchin Sterechinus neumayeri (Meissner 1900) and the sea-star Odontaster validus Koeler 1911 at Terra Nova Bay (Ross Sea): different strategies related to inter-annual variations in food availability. Polar Biol 25:251-255

Clarke A (1992) Reproduction in the cold: Thorson revisited. Invertebr Reprod Dev 22:175-184

Clough LM, Ambrose WG Jr, Ashjian CJ, Piepenburg D, Renaud PE, Smith SL (1997) Meroplankton abundance in the North-East Water Polynya: Insights from oceanographic parameters and benthic abundance patterns. J Mar Syst 10:343-357

Curtis MA (1975) The marine benthos of Arctic and subArctic continental shelves. Polar Rec 17:595-626

Day R, McEdward L (1984) Aspects of the physiology and ecology of pelagic larvae of marine benthic invertebrates. In: Steidinger KA, Walker LM (eds) Marine plankton life cycle strategies. CRC Press, Boca Raton, FL, p 93-120

Dayton PK (1990) Polar benthos. In: Smith WO (ed) Polar oceanography. Academic Press, New York, p 631-685

Dayton PK, Mordida BJ, Bacon F (1994) Polar marine communities. Am Zool 34:90-99

Deubel H, Engel M, Fetzer I, Gagaev S and others (2003) The Kara Sea ecosystem: phytoplankton, zooplankton and benthos communities influenced by river run-off. In: Stein R, Fahl K, Fütterer DK, Galimov EM, Stephanets OV (eds) Siberian river run-off in the Kara Sea: characterization, quantification, variability, and environmental significance. Elsevier, Amsterdam, p 237-266

Duda TF, Palumbi SR (1999) Developmental shifts and species selection in gastropods. Proc Natl Acad Sci USA 96: 10272-10277

Ekman S (1953) Zoogeography of the sea. Sidwick \& Jackson, London

Falk-Petersen IB (1982) Breeding season and egg morphology of echinoderms in Balsfjorden, Northern Norway. Sarsia 67:215-221

Fetzer I, Deubel H (2006) Effect of river-run off on the distribution of marine invertebrate larvae in the southern Kara Sea (Russian Arctic). J Mar Syst 60:98-114

Gajevskaja NS (1948) Fauna and flora of the northern seas of the UDSSR. Akademia Nauk Moscow, Moscow

Gallardo CS, Penchaszadeh PE (2001) Hatching mode and latitude in marine gastropods: Revisiting Thorson's paradigm in the southern hemisphere. Mar Biol 138:547-552

Geiger SR (1964) Echinodermata: larvae (Classes: Ophiuroidea and Echinoidea (Plutei)). ICES identification leaflets for plankton, Sheet 105. International Council for the Exploration of the Sea, Copenhagen

Golikov AN (1994) Shell-bearing molluscs of the Arctic Ocean. Tropa, Moskow

Groom TT (1894) On the early development of Cirripedia. Philos Trans Ser B 185:119-247

Grosberg RK(1987) Limited dispersal and proximity-dependent mating success in the sessile colonial ascidian Botryllus schlosseri. Evolution 41:372-384

Grosberg RK, Quinn JF (1986) The genetic control and consequences of kin recognition by the larvae of a colonial marine invertebrate. Nature 322:456-459

Hain S, Arnaud PM (1992) Notes on the reproduction of highAntarctic mollusks from the Weddell Sea. Polar Biol 12: 303-312

Hannerz L (1956) Larval development of the polychaete families Spionidae, Sars, Disomidae Mesnil, and Poecilochatidae n. fam. in the Gullmar Fjord, (Sweden). In: von Hofsten N, Hörstadius S, Jägersten G (eds) Zoologiske Bidrag, Vol 31. Almqvist \& Wiksells Boktryckeri, Uppsala

Hannerz L (1961) Polychaeta: larvae, families: Spionidae, Disomidae, Poecilochaetidae. ICES identification leaflets for plankton, Sheet 91. International Council for the Exploration of the Sea, Copenhagen

Hartmann-Schröder G (1996) Annelida, Borstenwürmer, Polychaeta. In: Dahl MG, Peus F (eds) Die Tierwelt Deutschlands, Teil 58. Gustav Fischer Verlag, Jena

Hoek PP (1907) Die Cirripedien des nordischen Planktons. In: Brandt K (ed) Nordisches Plankton, Teil 4. Asher, Amsterdam

Jablonski D, Lutz RA (1983) Larval ecology of marine benthic invertebrates: paleobiological implications. Biol Rev Camb Philos Soc 58:21-89

Jablonski D, Roy K (2003) Geographic range and speciation in fossil and living molluscs. Proc R Soc Lond B Biol Sci 270: 401-406

Johst K, Brandl R (1997) Evolution of dispersal: the importance of the temporal order of reproduction and dispersal. Proc R Soc Lond B Biol Sci 264:23-30

Korn OM, Kulikova VA (1995) Seasonal species composition and distribution of barnacle larvae in Avacha Inlet (Kamchatka). J Plankton Res 17:221-234

Lacalli TC (1980) A guide to the marine flora and fauna of the Bay of Fundy: polychaete larvae from Passamaquoddy Bay. Can Tech Rep Fish Aquat Sci 940:1-27

Lutz RA, Mann R, Goodsell JG, Castagna M (1982) Larval and early post-larval development of Arctica islandica. J Mar Biol Assoc UK 62:745-769

Makkaveev PN, Stunzhas PA (1994) Hydrochemical characteristics of the Kara Sea. Oceanology 34:600-605

Mileikovsky SA (1959) Interrelations between the pelagic larvae of Nephtys ciliata (O. F. Müller), Macoma baltica and Mya arenaria of the White Sea. Zool Zh 38:889-891 (in Russian with English Abstract)

Mileikovsky SA (1960) On the relation between temperature, spawning range of a species and its zoogeographical belonging in marine invertebrates. Zool Zh 39:666-669 (in Russian with English Abstract)

Mileikovsky SA (1966) The range of dispersal of the pelagic larvae of bottom invertebrates by ocean currents and its distributional role on the example of Gastropoda and Lamellibranchia. Okeanologiya 6:482-492 (in Russian with English Abstract)

Mileikovsky SA (1968) Distribution of pelagic larvae of bottom invertebrates of the Norwegian and Barents Sea. Mar Biol 1:161-167

Mileikovsky SA (1971) Types of larval development in marine bottom invertebrates, their distribution and ecological significance: a re-evaluation. Mar Biol 10:193-213

Mileikovsky SA (1974) Types of larval development in marine bottom invertebrates: an integrated ecological scheme. Thalassia Jugosl 10:171-179

Mironov E, Spinchkin VA, Egorov A (1994) Season variability and their variations in the region of the Barents and Kara Sea offshore. Proc 1st Int Conf Dev Russian Arctic Off- 
shore (RAO-93). St. Petersburg State Technical University, St. Petersburg, p 110-121

Mortensen T (1927) Handbook of the echinoderms of the British Isles. Oxford University Press, London

Mortensen T (1942) Nordisches Plankton: Echinodermata, Vermes (Zoologischer Teil). Medd Gronl 5:1-30

Muus K (1973) Settling, growth and mortality of young bivalves in the Øresund. Ophelia 12:78-116

Ockelmann KW (1958) The zoology of east Greenland: Marine Lamellibranchiata. Bianco Lunos Bogtrykkeri, Copenhagen

Ockelmann KW (1965) Developmental types in marine bivalves and their distribution along the Atlantic coast of Europe. In: Cox LR, Peake JF (eds) Proc 1st Europ Malacological Congress, London, 1962. Conchological Society of Great Britain and Ireland and the Malacological Society of London, London, p 25-35

Palma AT, Poulin E, Silva MG, Martín RBS, Muñoz CA, Díaz AD (2007) Antarctic shallow subtidal echinoderms: Is the ecological success of broadcasters related to ice disturbance? Polar Biol 30:343-350

Pavlov VK, Pfirman SL (1995) Hydrographic structure and variability of the Kara Sea: Implications for pollutant distribution. Deep-Sea Res 42:1369-1390

Pearse JS (1965) Reproduction periodicities in several contrasting populations of Odontaster validus Koehler, a common Antarctic asteroid. Antarct Res Ser 5:39-85

Pearse JS (1994) Cold-water echinoderms break 'Thorson's Rule'. In: Young CM, Eckelbarger KJ (eds) Reproduction, larval biology and recruitment of deep-sea benthos. Columbia University Press, New York, p 26-43

Pearse JS, Bosch I (1994) Brooding in the Antarctic: Östergren had it nearly right. In: David B, Guille A, Féral JP, Roux M (eds) Echinoderms through time. Balkema, Rotterdam, p 111-120

Pearse JS, Lockhart SJ (2004) Reproduction in cold water: paradigm changes in the 20th century and a role for cidaroid sea urchins. Deep-Sea Res II 51:1533-1549

Petersen GH (1966) Balanus balanoides (L.) (Cirripedia): life cycle and growth in Greenland. Medd Gronl 159:1-114

Piepenburg D (2005) Recent research on Arctic benthos: common notions need to be revised. Polar Biol 28:733-755

Plate S, Husemann E (1994) Identification guide to the planktonic polychaete larvae around the island of Helgoland (German Bight). Biologische Anstalt Helgoland, Hamburg, p 1-58

Poulin É, Féral JP (1998) Consequences of brood protection in the diversity of Antarctic echinoids. Océanis 24:159-188

Poulin É, Boletzky SV, Féral JP (2001) Combined ecological factors permit classification of developmental patterns in benthic marine invertebrates: a discussion note. J Exp Mar Biol Ecol 257:109-115

Poulin É, Palma AT, Féral JP (2002) Evolutionary versus ecological success in Antarctic benthic invertebrates. Trends Ecol Evol 17:218-222

Price R, Warwick RM (1980) Temporal variations in annual production and biomass in estuarine populations of two polychaetes, Nephtys hombergi and Ampharete acutifrons. J Mar Biol Assoc UK 60:481-487

Rasmussen E (1956) Faunistic and biological notes on marine invertebrates III. The reproduction and larval development of some polychaetes from the Isefjord, with some faunistic notes. Biol Medd K Dan Vidensk Selsk 23:1-84

Rasmussen E (1973) Isefjord fauna: general remarks. Ophelia 11:441-450

Raymont JEG (1983) Breeding of the meroplankton. In: Raymont JEG (ed) Plankton and productivity in the oceans. Pergamon Press, New York, p 449-488

Santos SL, Simon JL (1980) Marine soft-bottom community

Editorial responsibility: Otto Kinne,

Oldendorf/Luhe, Germany establishment following annual defaunation: Larval or adult recruitment? Mar Ecol Prog Ser 2:235-241

Sars GO (1895) An account of the Crustacea of Norway with short description of figures of all species: Amphipoda. Cammersmeyers Forlag, Christiania (Oslo)

Sars GO (1900) An account of the Crustacea of Norway with short description of figures of all species: Cumacea. Cammersmeyers Forlag, Christiania (Oslo)

Scheltema RS (1989) Planktonic and non-planktonic development among prosobranch gastropods and its relationship to the geographic range of species. In: Ryland JS, Tyler PA (eds) Reproduction, genetics and distribution of marine organisms. Olson \& Olson, Fredensborg, p 183-188

Schlüter M, Rachor E (2001) Meroplankton distribution in the central Barents Sea in relation to local oceanographic patterns. Polar Biol 24:582-592

Semenova TN, Mileikovsky SA, Nesis KN (1964) Morphology, distribution and seasonal occurence from larvae of the ophiuroid Ophiocten sericeum (Forbes) s.l. in the plankton of the north-western Atlantic, Norwegian and Barents Sea. Okeanologiya 4:669-683 (in Russian)

Sirenko BI (2001) List of species of free-living invertebrates of Eurasian Arctic seas and adjacent deep waters. Exploration of the faunas of the seas 51(59). Zoological Institute, Russian Academy of Science, St. Petersburg

Smidt ELB (1979) Annual cycles of primary production and of zooplankton at Southwest Greenland. Medd Gronl Biosci $1: 1-53$

Stanwell-Smith D, Peck LS, Clarke A, Murray AWA, Todd CD (1999) The distribution, abundance and seasonality of pelagic marine invertebrate larvae in the maritime Arctic. Proc R Soc Lond B Biol Sci 354:471-484

Stein R (2001) Geological core descriptions. Rep Polar Res 393:247-282

Stein R, Levitan M (2002) Lithogenic core descriptions. Rep Polar Res 419:234-274

Stephensen K (1942) The Amphipoda of northern Norway and Spitsbergen with adjacent waters. K. Karlsens Bok- \& Aksidenstrykkeri, Tromsø

Sveshnikov VA (1959) Types of reproduction and development of polychaetous worms in connection with their geographical distribution. Zool Zh 38:829-839 (in Russian with English Abstract)

Thatje S, Fuentes V (2003) First record of anomuran and brachyuran larvae (Crustacea: Decapoda) from Antarctic waters. Polar Biol 26:279-282

Thatje S, Hillenbrand C, Larter R (2005) On the origin of Antarctic marine benthic community structure. Trends Ecol Evol 20:534-540

Thomson Sir CW (1878) Notice of some peculiarities in the mode of propagation of certain echinoderms in the Southern Sea. Zool J Linn Soc Lond 13:55-79

Thorson G (1934) On the reproduction and larval stages of the brittlestars Ophiocten sericeum (Forbes) and Ophiura robusta Ayres in East Greenland. Medd Gronl 100:1-21

Thorson G (1936) The larval development, growth and metabolism of Arctic marine bottom invertebrates compared with those of other seas. Medd Gronl 100:1-155

Thorson G (1946) Reproduction and larval development of Danish marine bottom invertebrates, with special reference to the planktonic larvae in the sound (Øresund). CA Reitzels Forlag, Copenhagen

Thorson G (1950) Reproductive and larval ecology of marine bottom invertebrates. Biol Rev Camb Philos Soc 25:1-45

Volkov VA (2002) Polar seas oceanography: an integrated case study of the Kara Sea. Springer, Chichester

Zenkevitch L (1963) Biology of the seas of the USSR. Nauka, Moscow

Submitted: September 27, 2006; Accepted: October 2, 2007

Proofs received from author(s): March 6, 2008 